\title{
Polycyclic aromatic hydrocarbons (PAHs) in coastal sediments from urban and industrial areas of Asaluyeh Harbor, Iran: distribution, potential source and ecological risk assessment
}

\author{
Alireza Raeisi, Hossein Arfaeinia, Morteza Seifi, Mehdi Shirzad-Siboni, \\ Mozhgan Keshtkar and Sina Dobaradaran
}

\begin{abstract}
The distribution and toxicity levels of 16 EPA priority pollutant polycyclic aromatic hydrocarbons (PAHS) in the sediments of Asaluyeh shore, Iran were investigated. The total concentrations of the PAHs in surface sediments ranged from 1,054 to $17,448 \mathrm{ng} / \mathrm{g}$ dry weights with a mean concentration of $8,067 \mathrm{ng} / \mathrm{g}$. The spatial distribution of PAHs showed that PAH levels are much higher in the industrial areas in comparison with urban areas. Based on diagnostic ratios, pyrogenic activities were dominant sources of PAHs pollution in sediments comparing petroleum sources. The toxic equivalent concentrations (TEQ Carc) of PAHs ranged from 172 to 2,235 ng TEQ/g with mean value of 997.9. Toxicity levels were evaluated using sediment quality guidelines (SQGS) and toxic equivalent factors. Samples were collected from industrial and urban stations in Asaluyeh shores. According to SQGs, $\Sigma$ PAHs concentrations in sediments of urban areas were below the ERL (effects range low), but the industrial samples had $\Sigma$ PAHs concentrations between ERL and ERM (effects range median). Furthermore, 5 HPAHs (heavy PAHs) and some individual PAHs in some industrial stations exceeded ERM, indicating adverse ecological risk effects frequently occur. Findings demonstrate that the surface sediment from Asaluyeh shore is highly to very highly contaminated with PAHs.

Key words | polycyclic aromatic hydrocarbons (PAHs), risk assessment, sediment, sediment quality guidelines (SQGS), toxic equivalent concentrations (TEQ Carc)
\end{abstract}

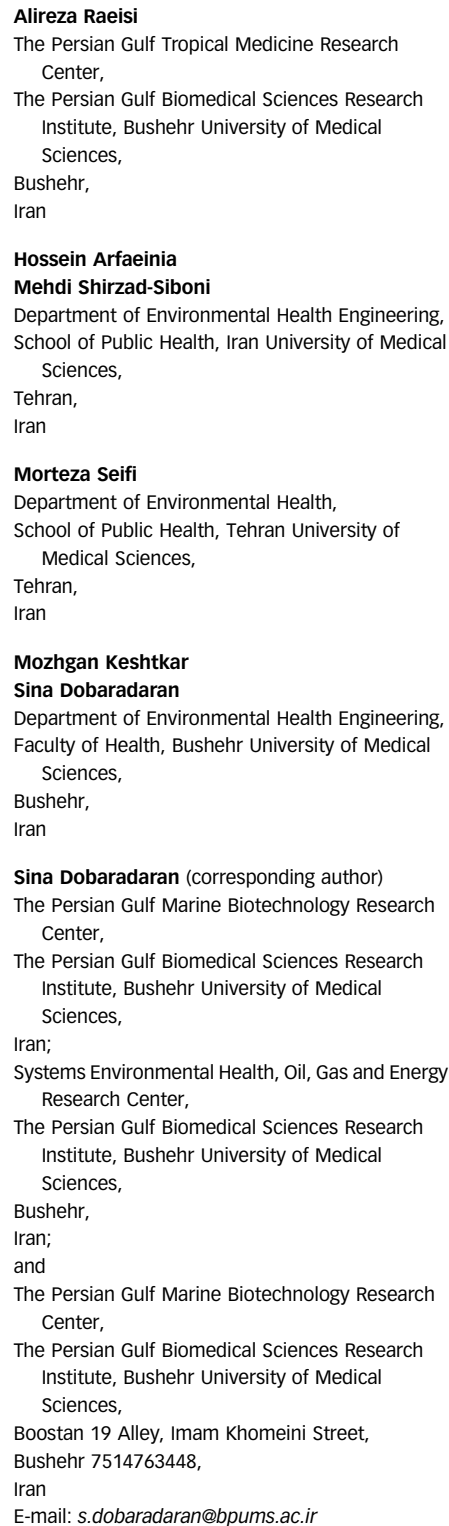




\section{INTRODUCTION}

Polycyclic aromatic hydrocarbons (PAHs) are a group of environmental pollutants generated by pyrolysis or incomplete combustion of organic materials, and consist of diverse groups of organic compounds (Menzie et al. 1992). The general structure of PAHs comprise two or more condensed aromatic rings arranged in various structural configurations (Liu et al. 2007). The PAHs that consist of fused aromatic rings containing up to four fused benzene rings are called light PAHs (LPAHS), and those consisting of more than four benzene rings are known as heavy PAHs (HPAHs). HPAHs are more toxic and more stable than the light ones (Wenzl et al. 2006).

Particular attention has been paid to PAH components due to their mutagenic and carcinogenic effects on humans (Man et al. 2013). Hence, PAHs have been included in the Environmental Protection Agency (EPA) and the European Commission priority pollutant lists (EPA 1993; European Commission 20II). Like chlorinated aliphatic hydrocarbons (Dobaradaran et al. 2010), PAH compounds can be present in the atmosphere, water, sediments, tobacco smoke and food (Wang et al. 200I; Yan et al. 2009). They may be emitted into the surroundings by natural processes and anthropogenic activities, but the latter is considered to be the main source of PAHs input into the environment (Zhou et al. 1998; Chen \& Chen 20II).

PAHs are present in the marine environment where they are linked with petrogenic, pyrolytic and diagenetic sources. The input route of PAHs to coastal water could be direct (e.g. continental runoff, sewage outflows and direct oil spills) or indirect (e.g. air-sea gas exchange and atmospheric deposition). A series of processes (e.g. volatilization, deposition, sinking, degradation and resuspension) determines the ultimate content of PAHs in the marine environment (Guitart et al. 20I0). PAHs compounds are hydrophobic with low water solubility and, thus, their concentrations in water are at low levels (Karcher 1988) because they tend to be absorbed by water-borne organic and inorganic particles. PAHs can be ultimately deposited and persist in sediment and aquatic marine ecosystems. In addition, the PAHs found in the bed sediment are resistant to bacterial degradation in an anoxic environment. Under favorable environmental conditions, deposited PAHs may be released into the water as a continuing source that threaten aquatic ecosystems by bioaccumulation in the food chain (Chen \& Chen 20II).

Asaluyeh is a city in and the capital of Asaluyeh County, in Bushehr Province, Iran. Asaluyeh is located on the shores of the Persian Gulf some $270 \mathrm{~km}$ southeast of the provincial capital of Bushehr. It is best known as the site for the land based facilities of the huge PSEEZ (Pars Special Energy Economic Zone) project. The PSEEZ has been allocated $100 \mathrm{~km}^{2}$ of land at Asaluyeh for the various complexes and facilities. The site is a collection of different petrochemical industries and refineries and is administered by the PSEEZ agency onsite. Rapid industrial development in the previous two decades, and especially the rapid increase of petrochemical industries, have led to serious concerns about environmental pollution (Arfaeinia et al. 2016). However, there is no information about pollution in Asaluyeh sediments.

The main objectives of this study were to: (1) determine the distribution, composition, and relative pollution levels of PAHs in industrial and urban sediments of Asaluyeh shore; (2) identify possible sources of PAHs; and (3) investigate the potential biological and toxicological effects on the environment.

\section{MATERIALS AND METHODS}

\section{Sampling}

Sediments used in this work were collected from 12 stations in urban and industrial areas (Figure 1). Sampling stations were chosen to ensure that samples would be representative and cover the whole shore water, be evenly distributed, and represent possible pollution sources so that a general evaluation of pollution levels of sediment could be effectively carried out. Onsite sampling of all 12 surface sediments was carried out during four months from September to December 2014, in Asaluyeh Harbor. Using the global positioning system, precise stations for each sampling point were identified. Surface sediments were collected using an Ekman steel grab sampler $(25 \times$ $25 \times 25 \mathrm{~cm}^{3}$ ). Sediment samples, from each station, were first mixed thoroughly and stored in glass jars, which had been pre-washed and stored in an icebox, then brought back to the laboratory for analysis. In the laboratory, sediments were freeze-dried for $48 \mathrm{~h}$, then wet sieved $(<0.5$ $\mathrm{mm})$ and homogenized completely. The dried samples were stored at $-20{ }^{\circ} \mathrm{C}$ in amber glass bottles which were pre-washed with n-hexane and covered with solventrinsed aluminum foil for analysis. 


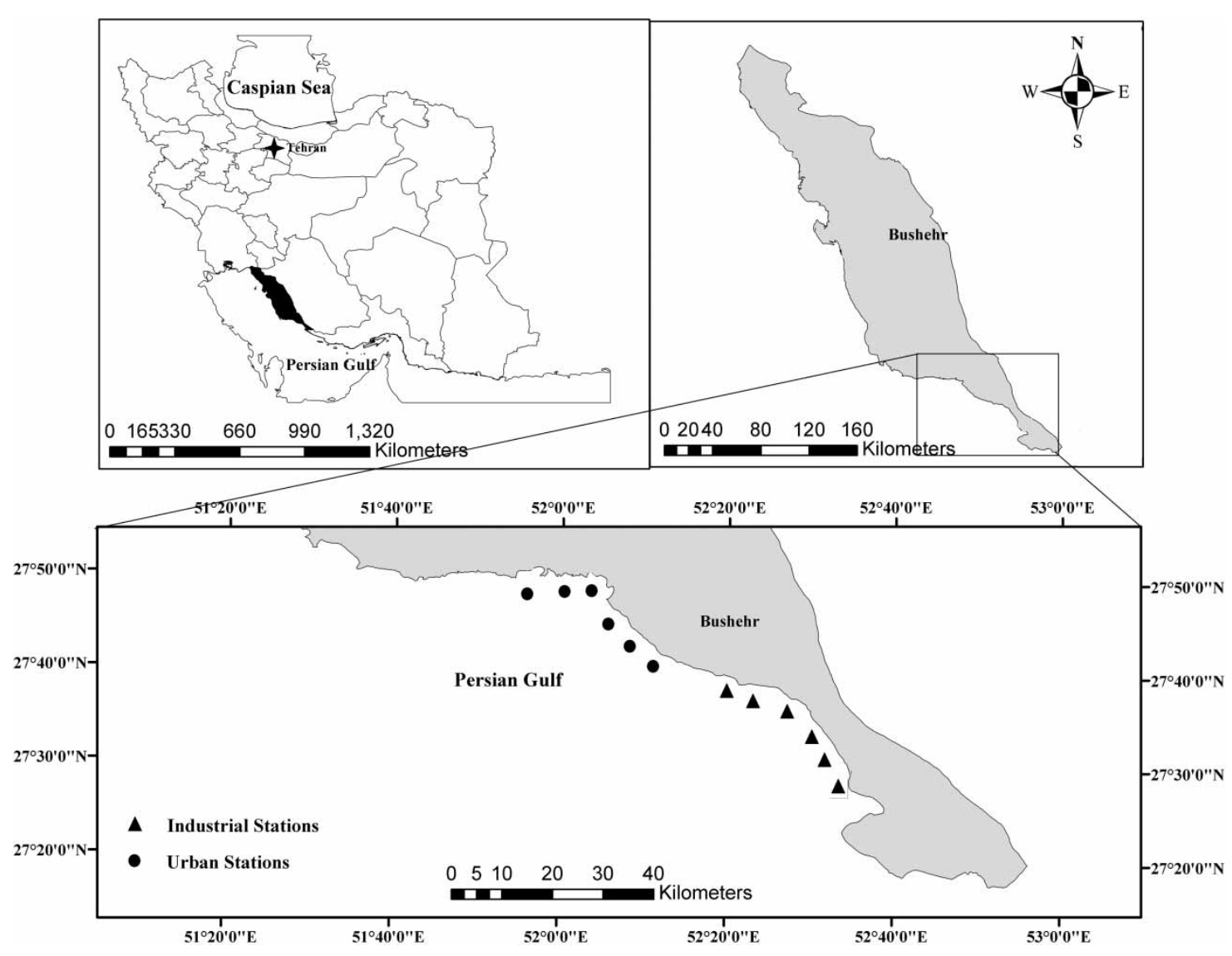

Figure 1 | Map of sampling stations.

\section{Chemicals}

Standards of 16 PAHs were obtained from Merck (Darmstadt, Germany) including naphthalene (NA), acenaphthene (ACE), acenaphthylene (ACY), phenanthrene $(\mathrm{PH})$, fluorene (FL), anthracene (AN), pyrene (PY), fluoranthene (FLU), benzo[a]anthracene (BaA), chrysene $(\mathrm{CH})$, benzo[b]fluoranthene $(\mathrm{BbF})$, benzo[a]pyrene $(\mathrm{BaP})$, benzo [k]fluoranthene (BkF), indeno[1,2,3-cd]pyrene (IP), and benzobenzo[g,h,i]perylene (BP), dibenzo[a,h]anthracene (DA), dichloromethane, n-hexane and other solvents of spectral purity level (United States World Company).

\section{Sample preparation and analysis}

Sediment size separation was carried out with a Coulter LS Particle Size Analyzer as reported by (Hung \& Hsu 2004; Chen et al. 2007). Three operational size fractions ( $>75 \mu \mathrm{m}, 2-75 \mu \mathrm{m},<2 \mu \mathrm{m}$ ) labeled as sand, silt and clay, respectively, were used to fraction each sediment sample. Wet sediment samples were heated in an oven at $105^{\circ} \mathrm{C}$ and at a constant weight. With respect to weight difference before and after heating, the water content of each sample was calculated. The dry sediments were heated again to $550^{\circ} \mathrm{C}$, and the weight difference before and after heating was considered as organic matter (APHA 200I).

For the PAH analysis, $10 \mathrm{~g}$ of each sample were mixed with $250 \mathrm{~mL}$ of $\mathrm{n}$-hexane:dichloromethane $(1: 1, \mathrm{v} / \mathrm{v})$, then the mixture was put in Soxhlet for $8 \mathrm{~h}$. The combined extract was evaporated on a rotary vacuum evaporator until $15 \mathrm{~mL}$ remained. To remove sulphur and their compounds, activated copper was added and passed through a filter paper (Whatman GF/ C, 24 micron) for $24 \mathrm{~h}$. The extract was concentrated in a rotary (Buchi B-490) to $5 \mathrm{~mL}$. The extract was passed through a column containing $10 \mathrm{~g}$ alumina, $2 \mathrm{~g}$ anhydrous sodium sulphate, and $10 \mathrm{~g}$ silica gel in n-hexane. Thereafter, $30 \mathrm{~mL}$ of a mixture of dichloromethane:nhexane $(9: 1, \mathrm{v} / \mathrm{v})$ was added. The mixture was concentrated again to $5 \mathrm{~mL}$. The extract was dried using a gentle stream of nitrogen (N-E VAP 112, USA). The residue was dissolved in $1 \mathrm{~mL}$ of acetonitrile (MOOPAM I999). 
A high performance liquid chromatographer (HPLC) (Waters 510, Milford, MA) equipped with a fluorescence detector (Waters 470) and autosampler (Waters 717) was used to detect the PAHs. The column type was RESTEK, Pinacle II PAH $(150 \times 3.2 \mathrm{~mm}, 5 \mu \mathrm{m})$ and the column temperature was set at $25^{\circ} \mathrm{C}$. Injection volume was $20 \mu \mathrm{L}$. The initial mobile phase was HPLC grade water: acetonitrile $(1: 1, \mathrm{v} / \mathrm{v})$ for $7 \mathrm{~min}$, which was gradually changed to $100 \%$ acetonitrile in $6 \mathrm{~min}$, held at $100 \%$ for $20 \mathrm{~min}$, then decreased to initial phase. Identification and determination of PAHs was standardized by the peak areas and retention times of the calibration standards.

\section{Quality assurance}

All data in this study were obtained under strict control procedures and quality assurances. Spiked blanks, laboratory blanks and replicate samples were tested together with the sediment samples. The recovery rate ranged from 81 to $94 \%$ with a relative standard deviation of 3-9\%. To monitor the quality control, procedural blanks were analyzed with every five samples. PAHs were not detected in any of the analytical blanks. Quantitative analysis was carried out on a five-point linear calibration of PAH solution, acquired by dilution of the 16-PAH mixture. Limit of detection was measured with a signal-to-noise ratio $(\mathrm{S} / \mathrm{N})$ of 3 . The method detection limit were between 0.1 and $1 \mathrm{ng} / \mathrm{g}$. Satisfactory linearity was obtained with values of the correlation coefficient $\mathrm{R}$ above 0.99 .

\section{Data analysis}

The results obtained were statistically analyzed using SPSS for Windows version 18 (SPSS Inc., Chicago, IL, USA). Data analyses, including mean, maximum and minimum concentrations, and standard deviation, were performed. A regression model was applied to test the relationship between sediment characteristics and PAH concentrations. The following data were analyzed: (a) the concentration of each PAH; (b) 16 PAHs; (c) the total of six PAHs with low molecular weight (ACY, NA, FL, ACE, PH, and AN); (d) 10 PAHs with high molecular weight (PY, FLU, BaA, CH, BkF, BbF, BaP, B, DA, and $\mathrm{IP})$; and (e) potential carcinogenic $\mathrm{PAHs}(\mathrm{BaA}, \mathrm{BbF}, \mathrm{CH}, \mathrm{BkF}$, IP, BaP, and DA).

$\Sigma \mathrm{CPAHs}$ (carcinogenic PAHs) including $\mathrm{BaA}, \mathrm{CH}, \mathrm{BbF}$, $\mathrm{BkF}, \mathrm{BaP}, \mathrm{IP}$, and DA according to (EPA I993), were used to calculate benzo[a]pyrene equivalents. The toxic equivalency factors (TEFs), the toxic factor of carcinogenic PAHs relative to benzo[a]pyrene (BaP), adopted by the EPA (I993), was calculated to assess sediment toxicity. The TEFs provided values for $\mathrm{BaA}=0.1, \mathrm{CH}=0.001, \mathrm{BbF}=0.1$, $\mathrm{BkF}=0.01, \mathrm{BaP}=1, \mathrm{DA}=1$, and $\mathrm{IP}=0.1$.

Sediment quality guidelines (SQGs) are an important issue and a significant tool for the evaluation of pollution effects on aquatic systems. In this study, SQGs were used to investigate the ecological and biological toxicity of PAHs concentrations in sediments (Long et al. 1998; Zeng et al. 2008). The US National Oceanic and Atmospheric Administration provide a sediment toxicity screening guideline which includes two target values to estimate potential biological effects: effects range low (ERL) and effects range median (ERM) (Long et al. 1995). These two values delineate three concentration ranges for each particular chemical. When the concentration of an environmental contaminant is below the ERL, it indicates that the biological effect is rare. If concentration equals to or is greater than the ERL, but below the ERM, it indicates that a biological effect would occur occasionally. Concentrations at or above the ERM indicate that a negative biological effect would frequently occur (Long et al. 1995).

Another approach to evaluate possible ecotoxicological effects of individual chemicals, by comparing the chemical concentrations with the limit concentrations, is the mean ERM quotient (m-ERM-q), which calculates the mean quotient for all PAHs. Based on Long et al. (I998, 2000) the mean ERM quotient (m- ERM-q) has been calculated using the following equation:

$\mathrm{M}-\mathrm{ERM}-\mathrm{Q}=\frac{\Sigma(\mathrm{Ci} / \mathrm{ERMi})}{\mathrm{n}}$

where $\mathrm{Ci}$ is the sediment concentration of compound $\mathrm{i}$, ERMi is the ERM value for compound $i$ and $n$ is the number of compounds. The m-ERM-q has been associated with the probability of toxicity, according to the matching of chemical and toxicity data from the US estuaries (Long et al. I998, 2000). The m-ERM-q can be classified into four groups including lower than $0.1,0.11$ to 0.51 , 0.51 to 1.5 and more than 1.5 which represent $11 \%, 30 \%$, $46 \%$ and $75 \%$ probability of toxicity, respectively (Long et al. 2000). Additionally, the above-mentioned groups can also categorize the stations as low, medium-low, mediumhigh and high priority sites, respectively (Chen et al. 20I3).

\section{RESULTS AND DISCUSSION}

\section{Concentrations and distribution of PAHs}

The organic matter contents and grain size (sand, silt and clay) distribution in sediment samples are shown in 
Table 1 | Stations, depth, grain size (sand, silt, and clay) and organic matter content of sediments in Asaluyeh shores

\begin{tabular}{|c|c|c|c|c|c|c|c|}
\hline Stations & Latitude ( $\mathrm{N}$ ) & Longitude ( E) & Water depth (m) & Clay (\%) & Silt (\%) & Sand $(\%)$ & Organic matter (\%) \\
\hline 1 & $27^{\circ} 40^{\prime} 39.1^{\prime \prime}$ & $52^{\circ} 16^{\prime} 29.4^{\prime \prime}$ & 6.7 & 12.5 & 60.4 & 27.1 & 7.4 \\
\hline 2 & $27^{\circ} 41^{\prime} 01.8^{\prime \prime}$ & $52^{\circ} 14^{\prime} 50.9^{\prime \prime}$ & 7.8 & 13.4 & 74.3 & 12.3 & 9.3 \\
\hline 3 & $27^{\circ} 41^{\prime} 19.9^{\prime \prime}$ & $52^{\circ} 13^{\prime} 49.1^{\prime \prime}$ & 9.3 & 8.2 & 58.6 & 33.2 & 11.1 \\
\hline 4 & $27^{\circ} 43^{\prime} 12.6^{\prime \prime}$ & $52^{\circ} 10^{\prime} 48.7^{\prime \prime}$ & 13.2 & 14.8 & 55.2 & 30 & 10.6 \\
\hline 5 & $27^{\circ} 44^{\prime} 33.6^{\prime \prime}$ & $52^{\circ} 09^{\prime} 03.2^{\prime \prime}$ & 7.4 & 9.4 & 76.4 & 14.2 & 8.1 \\
\hline 6 & $27^{\circ} 45^{\prime} 27.8^{\prime \prime}$ & $52^{\circ} 07^{\prime} 54.0^{\prime \prime}$ & 12.1 & 7.6 & 69.1 & 23.3 & 7.7 \\
\hline Mean of urban stations & - & - & $9.4 \pm 2.6$ & $10.9 \pm 2.9$ & $65.6 \pm 8.8$ & $23.3 \pm 8.4$ & $9 \pm 1.5$ \\
\hline 7 & $27^{\circ} 49^{\prime} 47.8^{\prime \prime}$ & $52^{\circ} 03^{\prime} 16.4^{\prime \prime}$ & 11.3 & 8.5 & 64.9 & 26.6 & 11.8 \\
\hline 8 & $27^{\circ} 50^{\prime} 12.4^{\prime \prime}$ & $52^{\circ} 02^{\prime} 54.1^{\prime \prime}$ & 8.2 & 16.8 & 53.2 & 30 & 14.3 \\
\hline 9 & $27^{\circ} 50^{\prime} 06.4^{\prime \prime}$ & $51^{\circ} 58^{\prime} 31.8^{\prime \prime}$ & 6.4 & 10.7 & 67.5 & 21.8 & 16.2 \\
\hline 10 & $27^{\circ} 50^{\prime} 04.3^{\prime \prime}$ & $51^{\circ} 56^{\prime} 47.7^{\prime \prime}$ & 10.5 & 9.1 & 61.4 & 29.5 & 15.8 \\
\hline 11 & $27^{\circ} 49^{\prime} 51.2^{\prime \prime}$ & $51^{\circ} 56^{\prime} 13.4^{\prime \prime}$ & 11.7 & 6.4 & 65.1 & 28.5 & 12.4 \\
\hline 12 & $27^{\circ} 49^{\prime} 36.6^{\prime \prime}$ & $51^{\circ} 55^{\prime} 29.5^{\prime \prime}$ & 7.4 & 12.6 & 74.9 & 12.5 & 9.6 \\
\hline Mean of industrial stations & - & - & $9.2 \pm 2.2$ & $10.6 \pm 3.6$ & $64.5 \pm 7.1$ & $24.8 \pm 6.7$ & $13.3 \pm 2.5$ \\
\hline Mean of all stations & - & - & $9.3 \pm 2.3$ & $10.8 \pm 3.1$ & $65 \pm 7.6$ & $24 \pm 7.3$ & $11.1 \pm 3.0$ \\
\hline
\end{tabular}

Table 1 . The mean value of grain size analyzed in 12 stations showed that the silt fraction represented $65 \%$ of total mass, followed by $24 \%$ sand and $10.8 \%$ clay. There were no significant differences between grain size sediment samples between urban and industrial stations.

As shown in Figure 2, the organic matter contents in industrial sediment were generally higher than in urban sediment. Total organic matter is one important factor that influences the PAHs levels in the sediments (Kim et al. 1999). Total organic matter content in sediment ranged from 7.4 to $16.2 \%$ which revealed the lowest and highest amount in stations 1 and 9 , respectively. The mean organic matter content of industrial sediment samples was higher than in urban areas.

A regression model was used to compare the relationship between $\Sigma$ PAHs content and organic matter. $\Sigma$ PAHs concentrations were log transformed for this analysis. Organic matter content and $\mathrm{PPAHs}$ associated significantly $(P<0.05)$ in 12 sampling stations according to the regression model. (Kim et al. 1999; Wang et al. 200I) pointed out that organic matter content can affect the PAHs distribution in sediments. In addition, some studies reported that there is a positive correlation between matter content and PAHs concentration in sediments (Yang 2000; Wang et al. 200I; De Luca et al. 2005). This was expected as it is well documented that hydrophobic organic substances will be mainly sorbed into particles through partition, which is in correlation with content of organic carbon (Zhou et al. I998; Chiou 2002). Our findings show that the organic matter content of sediment can influence the PAH distribution in sediments.

Marin et al. (2008) proposed a classification of ecological quality status concerning organic matter content into three levels: high-good (lower than 5\%), moderate (5\% to $10 \%$ ) and poor-bad (higher than 10\%). As shown in Table 1, stations 1, 2, 5, 6 and 12 indicated moderate qualities while other the stations $(3,4,7,8,9,10$ and 11) are classified as poor-bad. The abundant organic content of the sediment reveal that the organic accumulation would lead to the notable variations in sediment characteristics. The sediments with high organic matter content have a strong tendency for hydrophobic components, such as PAHs (Macrae \& Hall 1998; Xia \& Wang 2008). The high organic properties of the sediment could cause a reduction in oxygen so that anaerobic and unhealthy conditions would occur in sediments (Chen et al. 20I3).

The PAHs concentration in sediment samples of the 12 stations are shown in Tables 2 and 3 and in Figure 3. The amounts of total PAHs ( $\mathrm{PAHs}$ ) ranged from 1,054 to $17,448 \mathrm{ng} / \mathrm{g} \mathrm{dw}$ (dry weight) with an average value of $8,063 \pm 7,311 \mathrm{ng} / \mathrm{g} \mathrm{dw}$. The $\Sigma \mathrm{PAHs}$ in the industrial and urban stations averaged $14,953 \pm 1,814$ and $1,182 \pm 87 \mathrm{ng} / \mathrm{g}$, respectively. This shows that the industrial zone represents the main source of sediment PAHs.

Sediment PAHs composition of 12 stations from the Asaluyeh shores are presented in Figures 4 and 5. 16 PAHs components were categorized into three groups: (a) 2-, 3-ring, 


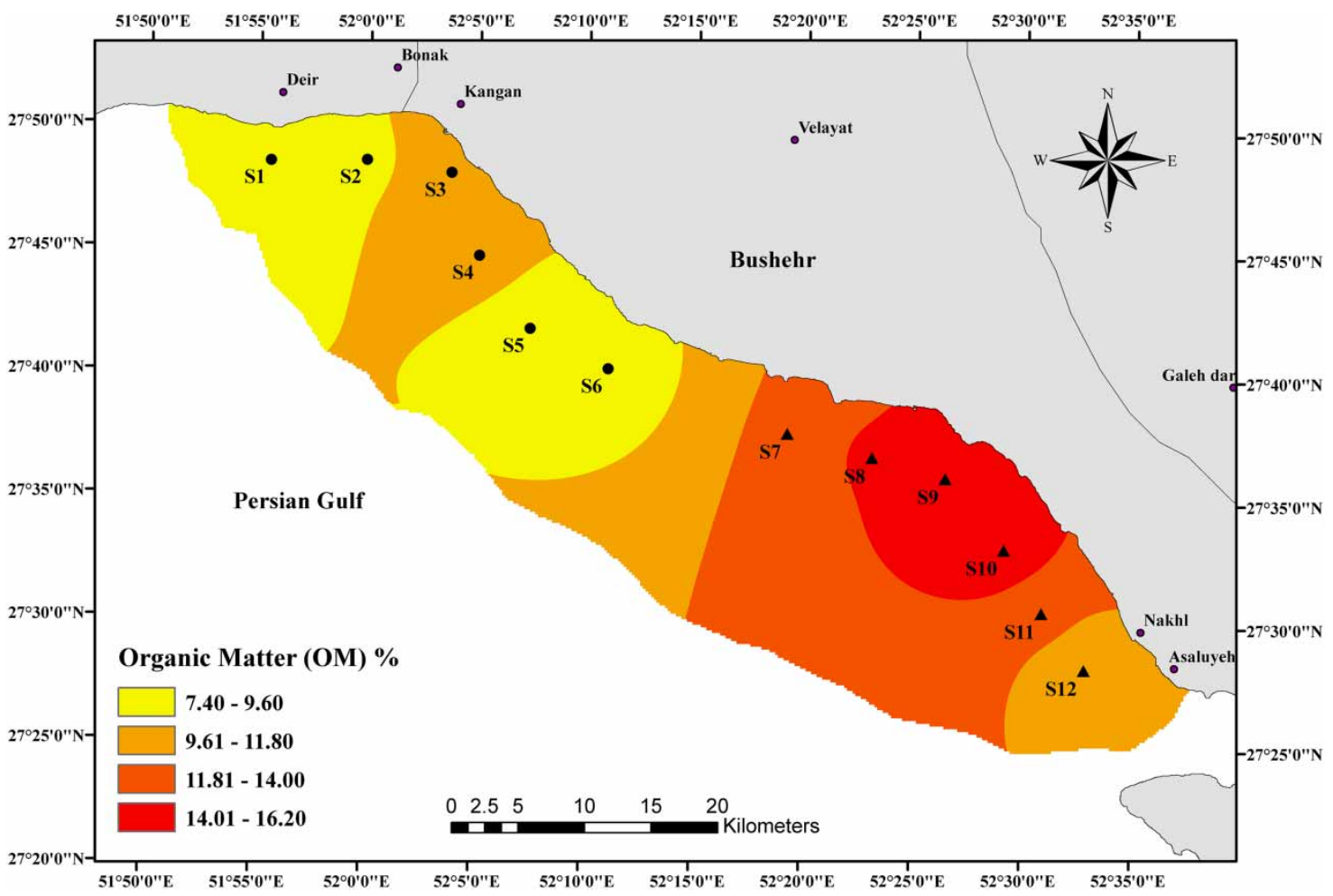

Figure 2 | Comparison of organic matter content among sediments samples collected from Asaluyeh shore.

(b) 4-ring, and (c) 5-, 6-ring PAHs. In four stations (1, 3, 7, and

8) 5- and 6-ring PAHs were most abundant whereas in stations 2, 4, 9, 10, 11 and 12 the 4-ring PAHs were highest. The overall levels of 2- and 3-ring PAHs were low, except in station 7. High-molecular-weight PAHs commonly predominated in sediment samples. The higher levels of highmolecular-weight in comparison with low-molecular weight $\mathrm{PAHs}$ has been reported in sediments from marine and river environments (Magi et al. 2002; Guo et al. 2007).

Factors, including differences in type and number of $\mathrm{PAH}$ compounds tested, geological features of sampling stations, and sediments fractioned, make it difficult to compare the PAHs values studied in different areas around the world. Although, a general knowledge of other sediment contamination would be helpful. PAHs concentrations in sediments in various locations around the world are indicated in Table 4.

Baumard et al. (1998) proposed a classification of PAH contamination and categorized $\Sigma \mathrm{PAHs}$ into four groups including: low $(0-100 \mathrm{ng} / \mathrm{g})$, moderate $(100-1,000 \mathrm{ng} / \mathrm{g})$, high $(1,000-5,000 \mathrm{ng} / \mathrm{g})$, and very high $(>5,000 \mathrm{ng} / \mathrm{g})$. Accordingly, sediments from Asaluyeh shore can be specified as high (stations 1-6) to very high (station 7-12) for PAH contamination.
A comparison between PAH concentrations in sediments from different studies is shown in Table 4. The PAH concentrations in surface sediment from Asaluyeh shore, in this study, are similar to those found at Gemlik Bay in Turkey (Ünlü \& Alpar 2006), Genoa-Voltri Harbor in Italy (Salvo et al. 2005), Kaohsiung Harbor in Taiwan (Chen et al. 20I3), and Lazaret Bay in France (Baumard et al. 1998), but lower than those detected in the Norwegian Harbour in Norway (Oen et al. 2006), Boston Harbor in the USA (Wang et al. 200I), and Xiamen Harbour in China (Hong et al. 1995). However, the levels were significantly higher than those found at the Pearl River Delta in China (Wang et al. 20Io), Daya Bay in China (Yan et al. 2009), Olbia Harbor in Italy (De Luca et al. 2005) and Incheon Harbor in Korea (Kim et al. 1999). As shown in Table 2, industrial stations have much higher levels of PAHs in comparison with urban sampling stations.

\section{Sources of PAHs from Asaluyeh shore}

There are two main sources of anthropogenic PAHs including combustion processes (pyrogenic sources) and leakage of noncombusted petroleum products (petrogenic sources) (Zakaria et al. 2002; Boonyatumanond et al. 2006). 
Table 2 | Measured concentrations ( $\mathrm{ng} / \mathrm{g} \mathrm{dW}$ ) of PAHs for sediments samples collected from Asaluyeh shore

\begin{tabular}{|c|c|c|c|c|c|c|c|c|c|c|c|c|c|c|c|c|c|}
\hline Station & & NA & ACY & ACE & FL & PH & AN & FLU & PY & BaA & CH & BbF & BkF & BaP & IP & DA & BP \\
\hline \multirow[t]{6}{*}{ Urban } & 1 & 79 & 11 & 13 & 9 & 28 & 4.7 & 145 & 128 & 83 & 63 & 201 & 132 & 134 & 23 & 43 & 19 \\
\hline & 2 & 68 & 7.4 & 9.6 & 21 & 22 & 2.8 & 173 & 184 & 98 & 113 & 167 & 98 & 108 & 15 & 36 & 35 \\
\hline & 3 & 70 & 8.7 & 8.9 & 13 & 27 & 3.4 & 111 & 98 & 110 & 54 & 234 & 117 & 97 & 8.9 & 69 & 13 \\
\hline & 4 & 57 & 14 & 5.4 & 6.8 & 45 & 2.7 & 210 & 194 & 131 & 63 & 114 & 84 & 123 & 19 & 54 & 15 \\
\hline & 5 & 38 & 8.3 & 19 & 27 & 17 & 1.9 & 148 & 112 & 173 & 125 & 268 & 158 & 91 & 26 & 33 & 43 \\
\hline & 6 & 86 & 16 & 15 & 15 & 39 & 4.7 & 243 & 189 & 80 & 49 & 179 & 101 & 169 & 13 & 47 & 32 \\
\hline $\begin{array}{c}\text { Mean of } \\
\text { urban } \\
\text { stations }\end{array}$ & & $66.3 \pm 17$ & $\begin{array}{c}10.9 \pm \\
3.4\end{array}$ & $\begin{array}{c}11.8 \pm \\
4.8\end{array}$ & $\begin{array}{c}15.3 \pm \\
7.5\end{array}$ & $\begin{array}{r}29.6 \pm \\
10.5\end{array}$ & $\begin{array}{r}3.3 \pm \\
1.1\end{array}$ & $\begin{array}{c}171.6 \pm \\
47\end{array}$ & $\begin{array}{c}150.8 \pm \\
42\end{array}$ & $\begin{array}{c}112.5 \pm \\
35\end{array}$ & $\begin{array}{c}77.8 \pm \\
32\end{array}$ & $\begin{array}{c}193.8 \pm \\
53\end{array}$ & $\begin{array}{c}115.0 \pm \\
26\end{array}$ & $\begin{array}{c}120.3 \pm \\
28\end{array}$ & $\begin{array}{c}17.4 \pm \\
6.4\end{array}$ & $\begin{array}{c}47.0 \pm \\
13\end{array}$ & $\begin{array}{c}26.1 \pm \\
12\end{array}$ \\
\hline \multirow[t]{6}{*}{ Industrial } & 7 & 1,539 & 179 & 661 & 437 & 1,512 & 195 & 1,742 & 998 & 934 & 738 & 1,471 & 1,439 & 998 & 238 & 116 & 441 \\
\hline & 8 & 1,928 & 68 & 329 & 359 & 930 & 103 & 1,334 & 1,529 & 745 & 962 & 1,023 & 1,783 & 1,431 & 543 & 129 & 287 \\
\hline & 9 & 2,004 & 93 & 438 & 674 & 1,630 & 239 & 2,145 & 1,739 & 1,821 & 1,023 & 1,517 & 1,695 & 1,243 & 349 & 257 & 563 \\
\hline & 10 & 1,348 & 56 & 373 & 593 & 1,156 & 98 & 2,234 & 2,431 & 1,321 & 673 & 1,714 & 1,979 & 1,764 & 547 & 92 & 419 \\
\hline & 11 & 890 & 173.4 & 540 & 180.7 & 1,330 & 194 & 1,590 & 1,129 & 984 & 1,327 & 871 & 1,378 & 1,065 & 412 & 143 & 349 \\
\hline & 12 & 2,338 & 45 & 213 & 246 & 1,278 & 207 & 1,981 & 1,764 & 1,290 & 971 & 1,921 & 1,042 & 1,398 & 614 & 203 & 193 \\
\hline \multirow{3}{*}{$\begin{array}{l}\text { Mean of } \\
\text { industrial } \\
\text { stations }\end{array}$} & & $\begin{array}{c}1,674.5 \pm \\
520\end{array}$ & $\begin{array}{c}102.4 \pm \\
59\end{array}$ & $\begin{array}{c}425.6 \pm \\
158\end{array}$ & $\begin{array}{c}414.9 \pm \\
192\end{array}$ & $\begin{array}{c}1,306.0 \pm \\
250\end{array}$ & $\begin{array}{c}172.6 \pm \\
58\end{array}$ & $\begin{array}{c}1,837.6 \pm \\
345\end{array}$ & $\begin{array}{l}1,598.3 \pm \\
514\end{array}$ & $\begin{array}{l}1,182.5 \pm \\
382\end{array}$ & $\begin{array}{c}868.2 \pm \\
232\end{array}$ & $\begin{array}{l}1,419.5 \pm \\
402\end{array}$ & $\begin{array}{l}1,552.6 \pm \\
26\end{array}$ & $\begin{array}{l}1,316.5 \pm \\
279\end{array}$ & $\begin{array}{c}435.0 \pm \\
125\end{array}$ & $\begin{array}{c}156.6 \pm \\
61\end{array}$ & $\begin{array}{c}384.0 \pm \\
115\end{array}$ \\
\hline & $\mathrm{ERL}^{\mathrm{a}}$ & 160 & 44 & 16 & 19 & 240 & 85.3 & 600 & 660 & 261 & 384 & - & - & 430 & - & 63.4 & - \\
\hline & $\mathrm{ERM}^{\mathrm{a}}$ & 2,100 & 640 & 500 & 540 & 1,500 & 1,100 & 5,100 & 2,600 & 1,600 & 2,800 & - & - & 1,600 & - & 260 & - \\
\hline
\end{tabular}

aERL and ERM refers to the ERL and median (Long et al. 1995). 
Table 3 PAHs concentrations ( $\mathrm{ng} / \mathrm{g} \mathrm{dw}$ ) and diagnostic ratios in sediments of Asaluyeh shore

\begin{tabular}{|c|c|c|c|c|c|c|c|c|c|c|c|c|c|}
\hline Station & IPAHS & ILPAHS & IHPAHS & ¿CPAHS & $\begin{array}{l}\text { ILPAHS/ } \\
\text { IHPAHS }\end{array}$ & PH/AN & $\begin{array}{l}\mathbf{A N} / \mathbf{P H}+ \\
\mathbf{A N}\end{array}$ & FLU/PY & $\begin{array}{l}\text { FLU/ } \\
\text { FLU }+ \text { PY }\end{array}$ & IP/BP & $\begin{array}{l}\text { m-ERM-q } \\
\text { (EPAHS) }\end{array}$ & $\begin{array}{l}\text { ICPAHS/ } \\
\text { IPAHS }\end{array}$ & TEQ Carc \\
\hline 1 & 1,125 & 145 & 971 & 679.1 & 0.15 & 5.96 & 0.14 & 1.13 & 0.53 & 1.21 & 0.043 & 0.60 & 209 \\
\hline 2 & 1,168 & 131 & 1,027 & 635.1 & 0.13 & 7.86 & 0.11 & 0.94 & 0.48 & 0.43 & 0.044 & 0.54 & 173 \\
\hline 3 & 1,054 & 131 & 912 & 690.0 & 0.14 & 7.94 & 0.11 & 1.13 & 0.53 & 0.68 & 0.049 & 0.65 & 203 \\
\hline 4 & 1,158 & 131 & 1,007 & 588.1 & 0.13 & 16.67 & 0.06 & 1.08 & 0.52 & 1.27 & 0.051 & 0.51 & 204 \\
\hline 5 & 1,300 & 111 & 1,177 & 874.2 & 0.09 & 8.95 & 0.10 & 1.32 & 0.57 & 0.60 & 0.045 & 0.67 & 172 \\
\hline 6 & 1,289 & 176 & 1,102 & 638.1 & 0.16 & 8.30 & 0.11 & 1.29 & 0.56 & 0.41 & 0.052 & 0.50 & 244 \\
\hline $\begin{array}{l}\text { Mean of urban } \\
\text { stations }\end{array}$ & $\begin{array}{l}1182.4 \pm \\
95\end{array}$ & $\begin{array}{c}137.5 \pm \\
21\end{array}$ & $\begin{array}{l}1032.6 \pm \\
94\end{array}$ & $684.1 \pm 99$ & $\begin{array}{r}0.13 \pm \\
0.02\end{array}$ & $\begin{array}{c}9.28 \pm \\
3.7\end{array}$ & $\begin{array}{r}0.11 \pm \\
0.03\end{array}$ & $\begin{array}{r}1.15 \pm \\
0.14\end{array}$ & $\begin{array}{r}0.53 \pm \\
0.03\end{array}$ & $\begin{array}{r}0.77 \pm \\
0.38\end{array}$ & $\begin{array}{r}0.047 \pm \\
0.003\end{array}$ & $\begin{array}{r}0.58 \pm \\
0.08\end{array}$ & $\begin{array}{r}201 \pm \\
26.6\end{array}$ \\
\hline 7 & 13,656 & 4,527 & 9,115 & $5,935.4$ & 0.50 & 7.75 & 0.11 & 1.75 & 0.64 & 0.54 & 0.581 & 0.43 & 1,393 \\
\hline 8 & 13,501 & 3,720 & 9,766 & $6,617.7$ & 0.38 & 9.03 & 0.10 & 0.87 & 0.47 & 1.89 & 0.509 & 0.49 & 1,810 \\
\hline 9 & 17,448 & 5,082 & 12,352 & $7,907.2$ & 0.41 & 6.82 & 0.13 & 1.23 & 0.55 & 0.62 & 0.740 & 0.45 & 1,887 \\
\hline 10 & 16,820 & 3,627 & 13,174 & $8,092.1$ & 0.28 & 11.80 & 0.08 & 0.92 & 0.48 & 1.31 & 0.611 & 0.48 & 2,235 \\
\hline 11 & 12,572 & 3,311 & 9,248 & $6,181.7$ & 0.36 & 6.86 & 0.13 & 1.41 & 0.58 & 1.18 & 0.519 & 0.49 & 1,450 \\
\hline 12 & 15,722 & 4,329 & 11,377 & $7,348.0$ & 0.38 & 6.17 & 0.14 & 1.12 & 0.53 & 3.18 & 0.582 & 0.47 & 1,995 \\
\hline $\begin{array}{l}\text { Mean of } \\
\text { industrial } \\
\text { stations }\end{array}$ & $\begin{array}{c}14,946 \pm \\
1,984\end{array}$ & $\begin{array}{c}4,099 \pm \\
661\end{array}$ & $\begin{array}{c}10,831 \pm \\
1,711\end{array}$ & $\begin{array}{l}7,013.7 \pm \\
903\end{array}$ & $\begin{array}{r}0.38 \pm \\
0.07\end{array}$ & $\begin{array}{c}8.07 \pm \\
2.0\end{array}$ & $\begin{array}{r}0.11 \pm \\
0.02\end{array}$ & $\begin{array}{r}1.22 \pm \\
0.33\end{array}$ & $\begin{array}{r}0.54 \pm \\
0.03\end{array}$ & $\begin{array}{r}1.28 \pm \\
0.65\end{array}$ & $\begin{array}{c}0.590 \pm \\
0.08\end{array}$ & $\begin{array}{r}0.47 \pm \\
0.02\end{array}$ & $\begin{array}{c}1,793 \pm \\
322\end{array}$ \\
\hline ERL & 4,022 & 552 & 1,700 & - & - & - & - & - & - & - & - & - & - \\
\hline ERM & 44,792 & 3,160 & 9,600 & - & - & - & - & - & - & - & - & - & - \\
\hline
\end{tabular}




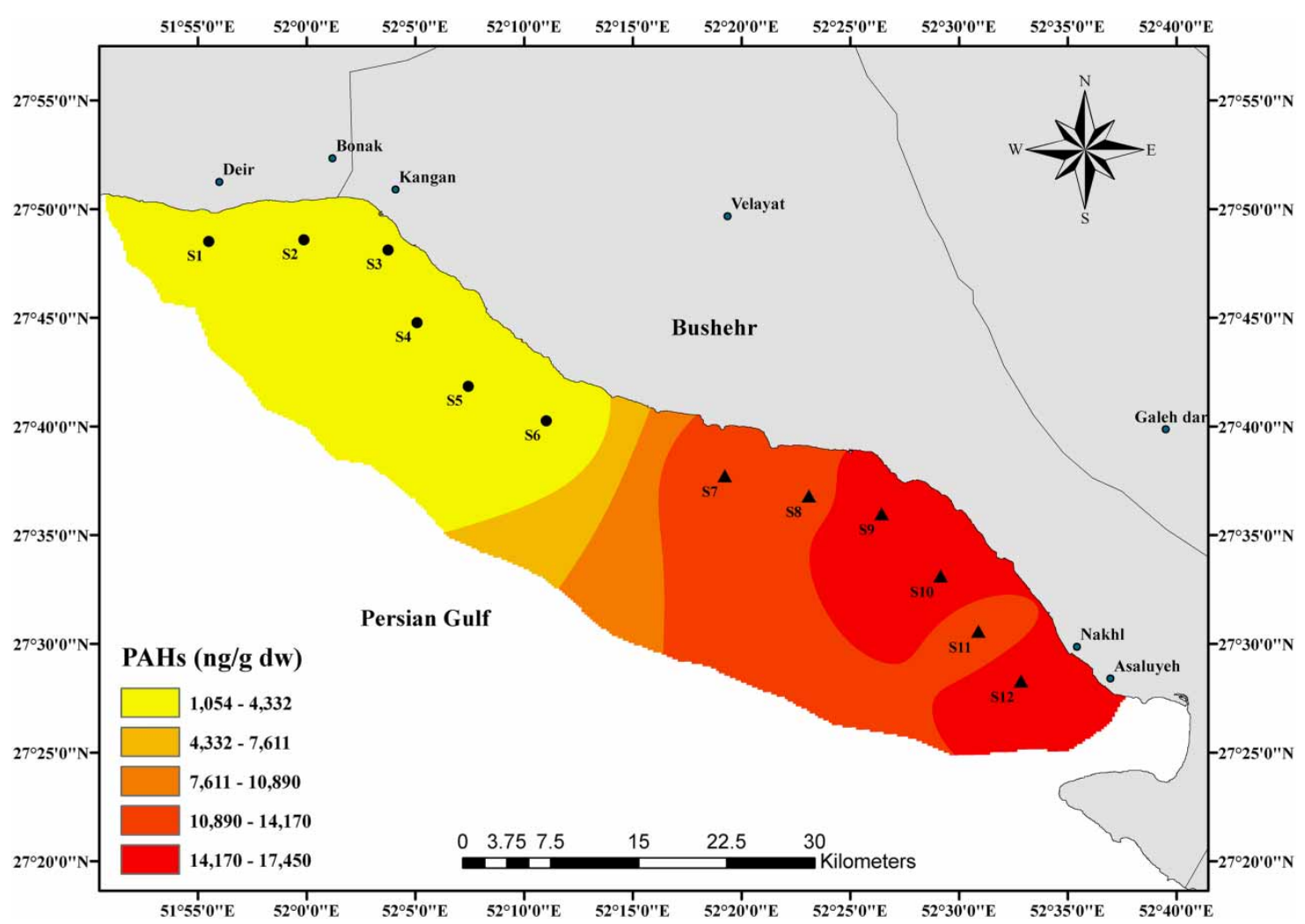

Figure 3 | Total PAHs contents in sediment samples of 12 stations from Asaluyeh shore.

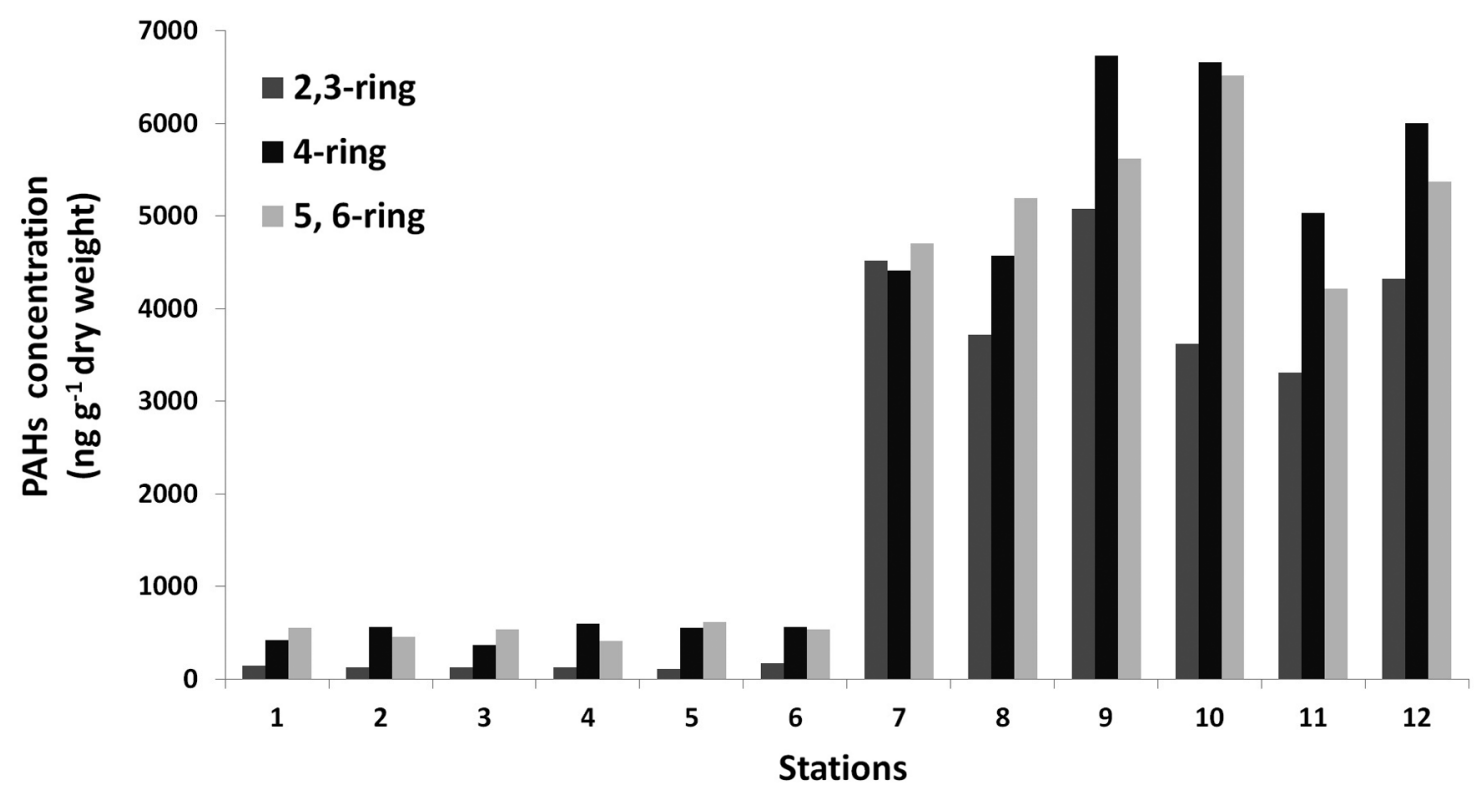

Figure 4 | PAHs composition based on benzene ring in sediment samples of 12 stations from Asaluyeh shore.

Depending on PAH composition and distribution patterns, different sources of PAHs in sediment samples can be identified. To distinguish sources of PAHs found in this study, a source analysis was carried out using PAHs isomeric ratios (ratios of individual PAH compounds) that have been widely used to determine various sources that contribute 

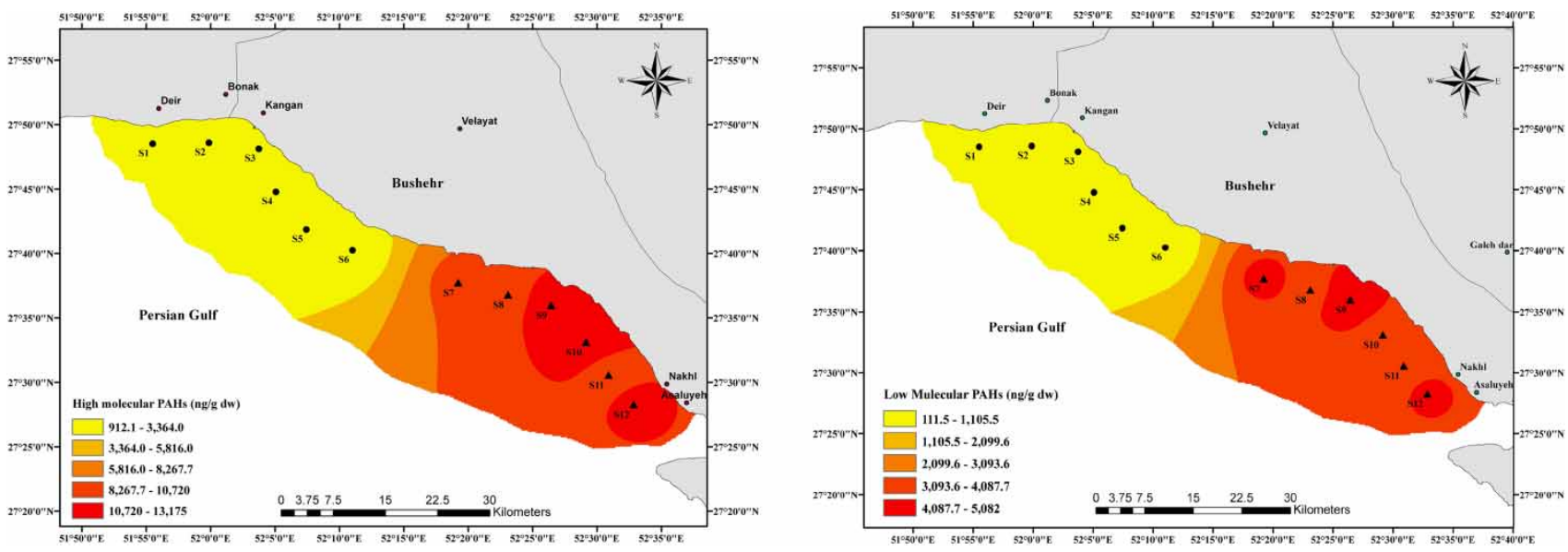

Figure 5 | PAHs composition based LPAHs and HPAHs in sediment samples of 12 stations from Asaluyeh shore.

PAHs to environmental samples (Soclo et al. 2000; Magi et al. 2002; Yunker et al. 2002; Fang et al. 2007; Jiang et al. 2009). The predominance of PAHs with low molecular weight (2- and 3-ring) have been linked to petrogenic sources (petroleum products), whereas PAHs with high molecular weight (4- to 6-ring) have a predominantly pyrogenic source (combustion process). Generally, a ratio of $\Sigma$ LPAHs/ $\Sigma$ HPAHs $<1$ indicates a pollution of pyrolytic (pyrogenic) origin and $>1$ suggests a pollution of petrogenic sources (Magi et al. 2002; De Luca et al. 2005). According to this classification, $\Sigma$ LPAHs/ $\Sigma$ HPAHs ratios in all Asaluyeh stations were $<1$, showing PAHs pollution originated from combustion processes (pyrogenic sources).

Additionally, other isomeric ratios have been developed for evaluating possible PAHs sources in sediment: (a) FLU/PY or, alternatively, FLU/(FLU + PY) (Guinan et al. 200I; Magi et al. 2002); (b) PH/AN or, alternatively, AN/ $(\mathrm{PH}+\mathrm{AN}$ ) ratio (Baumard et al. 1998; Soclo et al. 2000; Magi et al. 2002; Li et al. 2006; Qiao et al. 2006); (c) IP/BP (Yunker et al. 2002; Katsoyiannis et al. 2007).

The FLU/PY and FLU/(FLU + PY) ratios are helpful indicators in assessing the contribution of PAHs in sediment contamination. FLU/(FLU + PY) ratio $<0.4$ suggests petroleum sources, ratio $>0.5$ is attributed to the combustion process, whereas ratios between 0.4 and 0.5 are known to be from petroleum combustion sources (mixed sources). As shown in Figure 6, in the current study, the ratios of $\mathrm{FLU} /(\mathrm{FLU}+\mathrm{PY})$ at nine stations $(1,3,4,5,6,7,9,11$ and 12) were higher than 0.5 , indicating that pyrogenic sources played a major role in sediment pollution. The other stations were between 0.4 and 0.5 , implying that PAHs originated from mixed sources (petroleum combustion). Baumard et al. (I998) reported that the source of pollution is mainly from pyrogenic sources if the ratio of FLU/PY is higher than 1 . Their findings also demonstrated that petroleum discharges could increase the PAH levels in sediments if the ratio of FLU/PY is lower than 1. In this study, regarding contamination sources of 12 sampling stations, the results of the ratio of FLU/PY were completely similar to the results of $\mathrm{FLU} /(\mathrm{FLU}+\mathrm{PY})$ ratio (Figure 6).

The $\mathrm{PH} / \mathrm{AN}$ ratio is also a useful indicator to investigate the different sources of PAHs in sediments. The PH is thermodynamically more stable than AN, and higher concentrations of $\mathrm{PH}$ show that the PAHs pollution mainly originate from petroleum inputs. Indeed, petrogenesis activities cause a high $\mathrm{PH} / \mathrm{AN}$ ratio. According to previous research, when the $\mathrm{PH} / \mathrm{AN}$ ratio is higher than 10 , this indicates that sediment is mainly polluted by petroleum products, and a PH/AN ratio lower than 10 shows that PAHs in sediment originate from pyrogenic activities (Baumard et al. 1998; Qiao et al. 2006). As shown in Table 3, the PH/AN ratio and $\mathrm{AN} /(\mathrm{PH}+\mathrm{AN})$ ratio, at most stations, were lower than 10 and higher than 0.1 , respectively. This means that the major source of PAHs was from combustion processes. In stations 4 and 10 , the ratio of $\mathrm{PH} / \mathrm{AN}$ and $\mathrm{AN} / \mathrm{PH}+$ AN) were higher than 10 and less than 0.1 , respectively, showing petrogenic activities (Figure 6).

IP/BP ratio is another PAH isomeric ratio used to identify PAHs sources in sediment (Yunker et al. 2002; Brändli et al. 2007). When the ratio of IP/BP is lower than 0.2, sources are related to petrogenic inputs, and if higher than 0.5 , sources are related to combustion processes, and ratios between 0.2 and 0.5 correspond to petroleum combustion. In this study, the IP/BP ratios at most stations were higher than 0.5 except in stations 2 and 6 which were between 0.2 and 0.5 . Therefore, according to this isometric 
Table 4 IPAHs concentrations (ng/g dw) in sediments at different stations around the world (the pollution levels are assigned as low: 0-100 ng/g dw, moderate: 100-1,000 ng/g dw, high: 1,000-5,000 ng/g dw, very high: >5,000 ng/g dw (Baumard et al. 1998)

\begin{tabular}{|c|c|c|c|c|}
\hline Area & $\mathbf{n}^{\mathbf{a}}$ & IPAHs (ng/g dw) & Level of pollution & Literature \\
\hline Asaluyeh shores, Iran & 16 & $1,053-17,439$ & High to very high & Current study \\
\hline Kaohsiung Harbor, Taiwan & 17 & $34-16,700$ & Low to very high & Chen et al. (20I3) \\
\hline Kaohsiung Harbor, Taiwan & 17 & $472-16,207$ & Moderate to very high & Chen \& Chen (20II) \\
\hline Pearl River Delta, China & 15 & $52.7-717$ & Low to moderate & Wang et al. (20Io) \\
\hline Daya Bay, China & 16 & $42.5-158.2$ & Low & Yan et al. (2009) \\
\hline Yangtze Estuary, China & 17 & $107-633$ & Moderate & Liu et al. (2008) \\
\hline Gemlik Bay, Turkey & 14 & $50.8-13,482$ & Low to very high & Ünlü \& Alpar (2006) \\
\hline Commercial ports from Spain & 12 & $260-66,710$ & Moderate to very high & Casado-Martinez et al. (2006) \\
\hline Norwegian Harbor, Norway & 16 & $2,000-76,000$ & High to very high & Oen et al. (2006) \\
\hline Genoa-Voltri Harbor, Italy & 16 & $4,500-20,800$ & High to very high & Salvo et al. (2005) \\
\hline Olbia Harbor, Italy & 16 & $160-770$ & Moderate & De Luca et al. (2005) \\
\hline Western Harbor, Alexandria, Egypt & 20 & $8-131,150$ & Low to very high & Notar et al. (200I) \\
\hline Hsin-ta Harbor, Taiwan & 30 & $1,156-3,382$ & High & Fang et al. (2003) \\
\hline Santander Bay, Northern & 16 & $20-25,800$ & Low to very high & Viguri et al. (2002) \\
\hline Boston Harbor, USA & 16 & $7,300-358,000$ & Very high & Wang et al. (200I) \\
\hline Izmit Bay, Turkey & 17 & $2,500-25,000$ & High to very high & Tolun et al. (200I) \\
\hline Taranto Gulf, Italy & 8 & $335-5193$ & Moderate to very high & Storelli \& Marcotrigiano (2000) \\
\hline Baltimore Harbor, USA & 21 & $2,944-29,590$ & High to very high & Pereira et al. (I999) \\
\hline Incheon Harbor, Korea & 23 & $12-1,400$ & Low to moderate & Kim et al. (1999) \\
\hline Lazaret Bay, France & 26 & 13,000 & Very high & Baumard et al. (I998) \\
\hline Ajaccio Harbor, Corsica & 26 & 20,140 & Very high & Baumard et al. (I998) \\
\hline Torres Harbor, Sardinia & 26 & 920 & Moderate & Baumard et al. (I998) \\
\hline Victoria Harbor, Hong Kong & 9 & $1,200-14,000$ & High to very high & Hong et al. (I995) \\
\hline Xiamen Harbor, China & 9 & $2,900-61,000$ & High to very high & Hong et al. (1995) \\
\hline Coastal sediment, Thermaikos Gulf, Greece & 16 & $580-930$ & Moderate & Kilikidis et al. (I994) \\
\hline
\end{tabular}



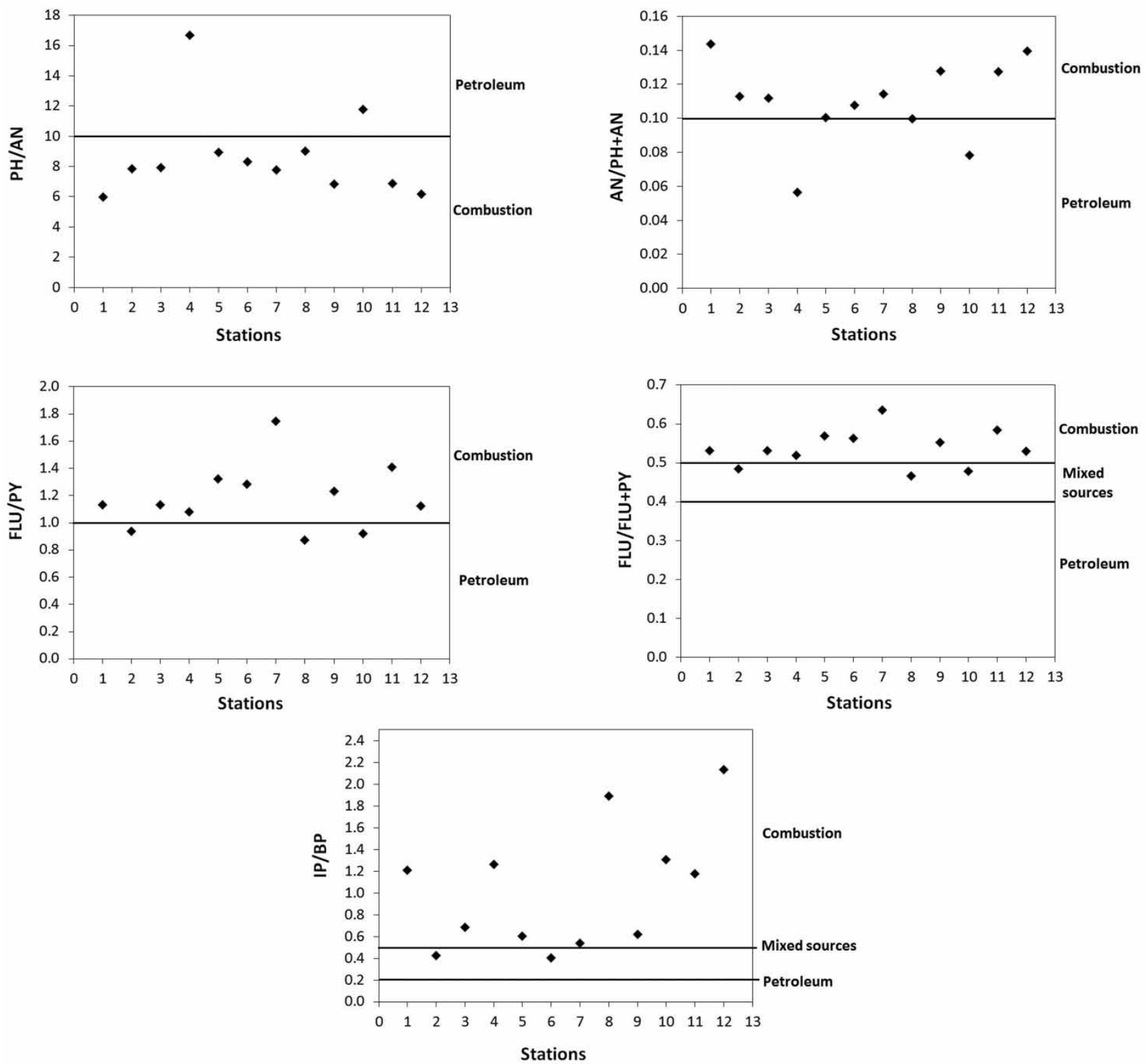

Figure 6 | Plot of isomeric ratios PH/AN, AN/PH + AN, FLU/PY, FLU/FLU + PY and IP/BP.

ratio, pyrogenic sources were dominant (Figure 6). Based on several PAHs isomeric ratios used in this study, sediment pollution of Asaluyeh shore mainly originated from combustion processes (pyrogenic sources).

\section{Potential human toxicity and biological effects of PAHs}

Sediment carcinogenicity was evaluated in this study according to total quantity of seven potentially human carcinogenic PAHs including $\mathrm{BaA}, \mathrm{CH}, \mathrm{BbF}, \mathrm{BkF}, \mathrm{BaP}, \mathrm{IP}$, and DA (Savinov et al. 2003; Nadal et al. 2004; Qiao et al.
2006). As indicated in Table 3 and Figure 7, mean values of $\Sigma$ CPAHs, in urban and industrial stations, were $684.1 \pm$ 99 and $7013.7 \pm 903$, respectively. In addition, $\Sigma$ CPAHs accounted for $43 \%$ to $67 \%$ of $\Sigma$ PAHs in acquired samples of Asaluyeh sediments.

$\mathrm{BaP}$ is a good indicator of carcinogenic potency of sediment PAHs. Hence, the potential carcinogenicity was surveyed using the total toxic BaP equivalent (TEQ Carc) (Savinov et al. 2003; Nadal et al. 2004).

In this study, the total TEQ Carc rates of sampled sediments ranged from 172 to $2,235 \mathrm{ng}$ TEQ $\mathrm{g}^{-1} \mathrm{dw}$, and the 


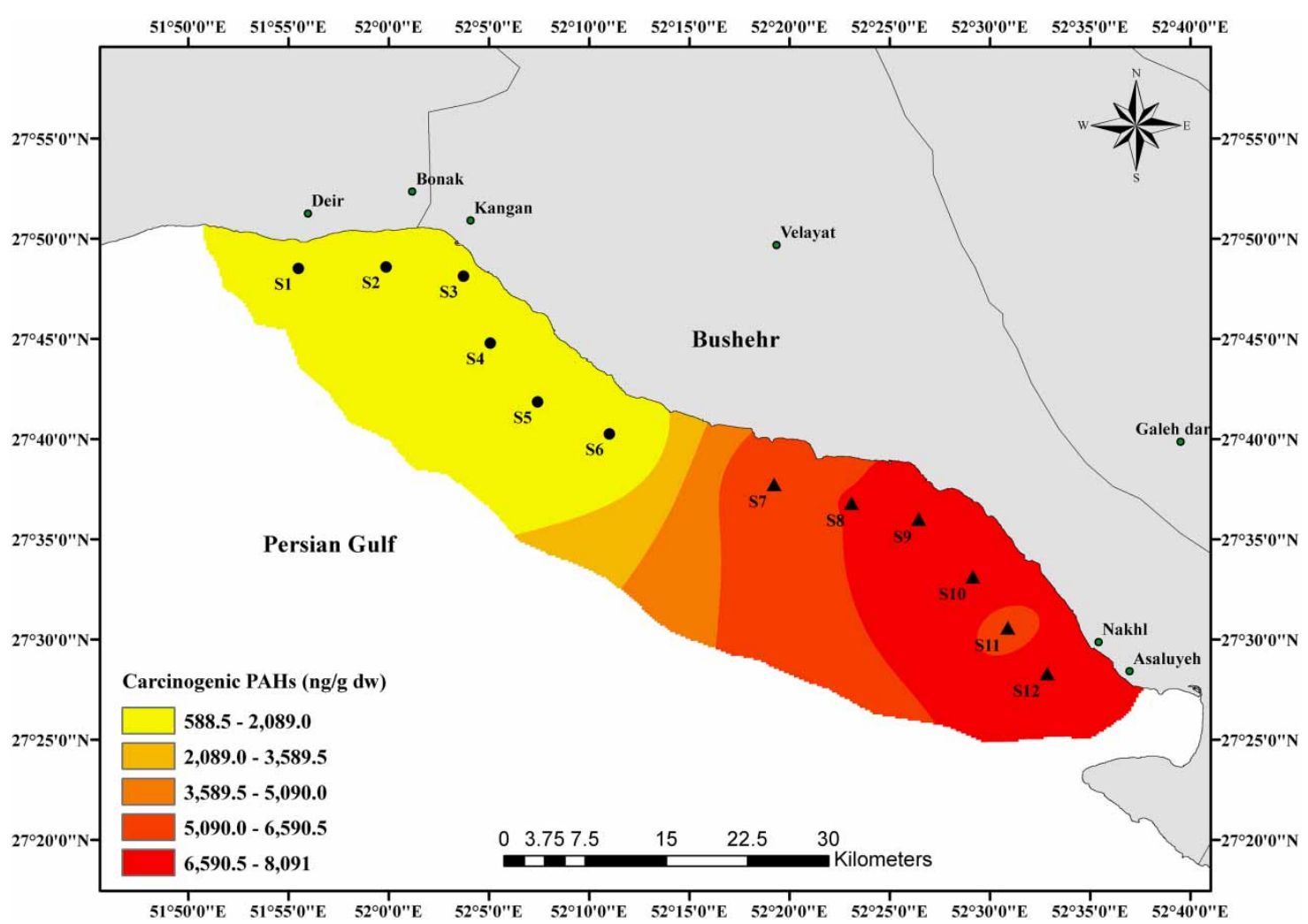

Figure 7 | CPAHs contents in sediment samples of 12 stations from Asaluyeh shore.

average value was $998 \mathrm{ng} \mathrm{TEQ} \mathrm{g}^{-1} \mathrm{dw}$. In addition, the total TEQ Carc values in industrial and urban stations averaged between 201 and 1,795 ng TEQ $\mathrm{g}^{-1} \mathrm{dw}$, respectively. Much higher pollution was seen in industrial stations compared with urban areas.

The findings of TEQ Carc in this study were consistent with sediments from Kaohsiung Harbor, Taiwan (55-1,964 ng TEQ $\mathrm{g}^{-1} \mathrm{dw}$ ), but higher than those reported in the Barents Sea, Russia (19-733 ng TEQ g-1 dw) and in Meiliang Bay, China (94-845 ng TEQ g-1 dw), but were lower than those reported from Naples Harbor, Italy (2-4,723 ng TEQ g-1 dw) (Chen \& Chen 20II; Qiao et al. 2006; Sprovieri et al. 2007).

SQGs have been widely used for contaminated sediment assessment (Bothner et al. 1998; Connor et al. 1998; Wakeman \& Themelis 200I; Birch \& Taylor 2002; Jones-Lee \& Lee 2005; Roach 2005). ERL and ERM are considered guidelines to help categorize the range of environmental contaminants. If concentrations are lower than ERL, this means that the biological effects are scarcely observed. If concentrations are equal to or greater than the ERL but below the ERM, it shows that a negative biological effect would occur occasionally. Concentrations at or above the
ERM indicate that a negative biological effect would frequently occur (Long et al. 1995).

SQGs (ERM and ERL values) in comparison with quantified PAHs in sediments of Asaluyeh are shown in Tables 2 and 3. $\Sigma \mathrm{PAHs}$ concentrations in sediment of urban areas (stations 1-6) were below the ERL, but all the industrial stations had $\Sigma$ PAHs concentrations above the ERL and lower than ERM. Regarding $\Sigma$ LPAHs, all of the urban sediment samples were below the ERL, whereas all of the industrial samples exceeded ERM. $\mathrm{LHPAHs}$ were below the ERL in urban samples, between ERL and ERM in stations 7 and 11, but exceeded ERM in stations 8-10 and 12 which implies that biological effects could occur frequently. Additionally, some individual PAHs exceeded ERM in industrial sediments including NA at station 12, ACE at stations 7 and 11, FL at stations 9 and 10, PH at stations 7 and $9, \mathrm{BaA}$ at station 9 and $\mathrm{BaP}$ at station 10 . In general, these results show that adverse ecotoxicological risk effects rarely occur in urban areas, occasionally occur in industrial areas, and frequently occur in some industrial stations. Industrial areas, due to various anthropogenic inputs, represent higher potential negative biological effects compared with urban areas. 


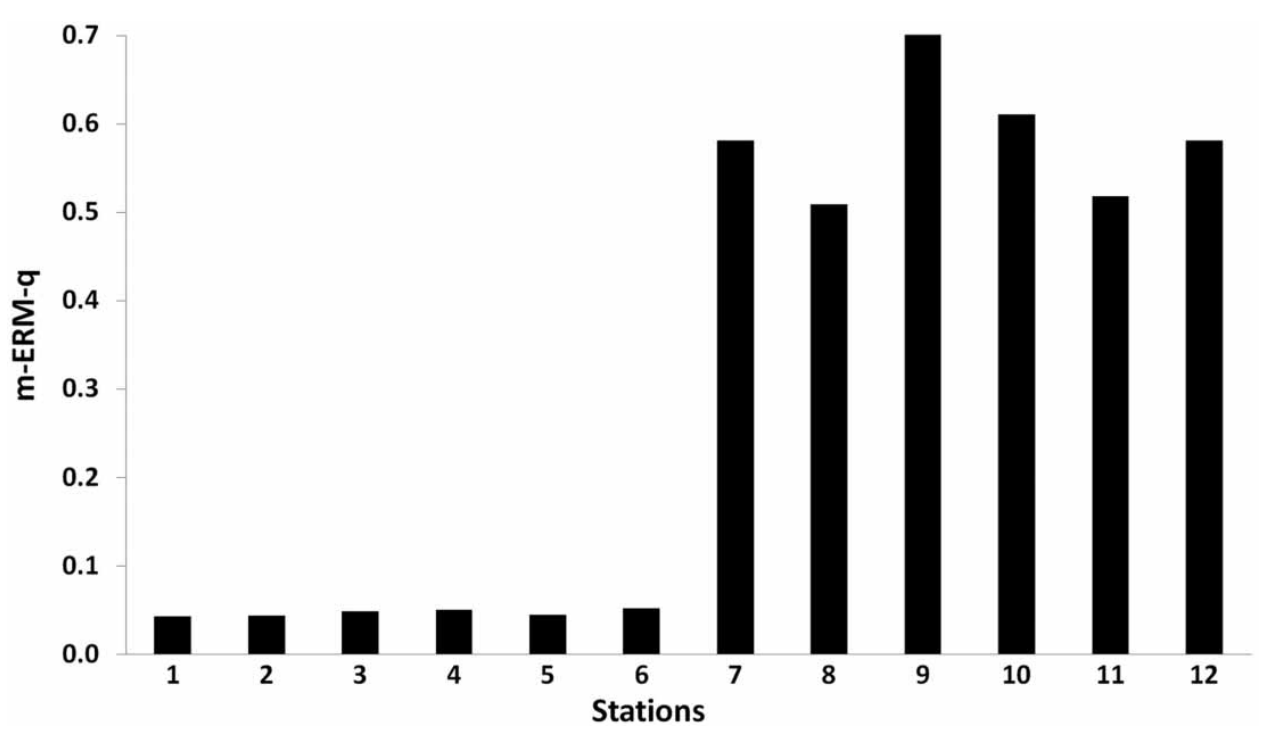

Figure 8 | The m- ERM-q values of sediment samples in 12 stations from Asaluyeh shore.

The m-ERM-q of $\Sigma$ PAHs in 12 sampling stations is shown in Table 3 and Figure 8 . The m-ERM-q of $\Sigma$ PAHs rates in sediment from 12 stations ranged from 0.043 to 0.740 with a mean value of $0.319 \pm 0.28$. Stations $1-6$ (urban areas) are specified as a low group (11\% probability of toxicity), and stations 7-12 (industrial areas) are specified as a medium-high group (46\% probability of toxicity).

However, even though the SQGs sets can somewhat predict the possible ecological toxicity of chemical contaminants, these sets do not consider chemical bioavailability and are not based on experiments (Long et al. 200o). Additionally, since data from all chemical contaminates, and possible negative effects are not available, SQGs cannot represent a comprehensive picture of sediments quality. Nevertheless, the value range gives for quick information for the identification of sediment quality and the ecological and biological toxicity (Long et al. 1998, 2000). Therefore, this measure is useful for an initial ecological risk assessment. Due to negative carcinogenic, teratogenic and environmental effects caused by the presence of this pollutant in our water systems, it is essential to continue conducting local biological toxicity experiments in order to protect against a pollution problem reaching a stage in which the livelihood of local residents and health of the local environment can no longer be sustained.

In this study, only PAH pollutants were evaluated in the northern part of the Persian Gulf, whereas there are several concerning pollutants such as polychlorinated biphenyls and dioxin that could increase along the Persian Gulf in Asaluyeh shores due to industrial activities. Therefore, the present study presents primary data on the assessment of sediment quality in Asaluyeh shores. In the near future, we hope to perform more projects to obtain comprehensive data on various possible pollutants in the sediments and seawaters along the Persian Gulf in this area.

\section{CONCLUSION}

This research provides important information on PAH levels in surface sediments of the Asaluyeh shore. A positive correlation was found between organic matter content and PAHs concentrations in sediments samples. The results show that the surface sediment from Asaluyeh shore is high to very highly contamination and PAH levels in industrial stations were much higher than in urban stations. Based on several PAHs isomeric ratios, sediment pollution mainly originated from combustion processes (pyrogenic sources). $\mathrm{P}$ PAHs concentrations in sediments from urban areas were below the ERL, but all the industrial samples had $\Sigma$ PAHs concentrations between ERL and ERM. Additionally, $\Sigma$ HPAHs and some individual PAHs in some industrial stations exceeded ERM, indicating that adverse ecotoxicological risk effects could frequently occur. The findings of our study suggest that industrial activities play important roles in increasing $\mathrm{PAH}$ pollution in sediments of Asaluyeh shore.

\section{ACKNOWLEDGEMENTS}

This project was supported by the Bushehr University of Medical Sciences (Grant No. 20/71/8013) and partially supported by Iran University of Medical Sciences, Iran. 


\section{REFERENCES}

APHA 200I Standard Methods for the Examination of Water and Wastewater, 21st edn. American Public Health Association, Washington, DC, USA.

Arfaeinia, H., Nabipour, I., Ostovar, A., Asadgol, Z., Abuee, E., Keshtkar, M. \& Dobaradaran, S. 2016 Assessment of sediment quality based on acid-volatile sulfide and simultaneously extracted metals in heavily industrialized area of Asaluyeh, Persian Gulf: concentrations, spatial distributions, and sediment bioavailability/toxicity. Environmental Science and Pollution Research 9, 1-20.

Baumard, P., Budzinski, H. \& Garrigues, P. 1998 Polycyclic aromatic hydrocarbons in sediments and mussels of the western Mediterranean Sea. Environmental Toxicology and Chemistry 17, 765-776.

Birch, G. F. \& Taylor, S. E. 2002 Assessment of possible sediment toxicity of contaminated sediments in Port Jackson, Sydney, Australia. Hydrobiologia 472, 19-27.

Boonyatumanond, R., Wattayakorn, G., Togo, A. \& Takada, H. 2006 Distribution and origins of polycyclic aromatic hydrocarbons (PAHs) in riverine, estuarine, and marine sediments in Thailand. Marine Pollution Bulletin 52, 942-956.

Bothner, M., Gill, P., Boothman, W., Taylor, B. \& Karl, H. I998 Chemical gradients in sediment cores from an EPA reference site off the Farallon Islands - assessing chemical indicators of dredged material disposal in the deep sea. Marine Pollution Bulletin 36, 443-457.

Brändli, R. C., Bucheli, T. D., Kupper, T., Mayer, J., Stadelmann, F. X. \& Tarradellas, J. 2007 Fate of PCBs, PAHs and their source characteristic ratios during composting and digestion of source-separated organic waste in full-scale plants. Environmental Pollution 148, 520-528.

Casado-Martinez, M. C., Buceta, J. L., Belzunce, M. J. \& DelValls, T. 2006 Using sediment quality guidelines for dredged material management in commercial ports from Spain. Environment International 32, 388-396.

Chen, C.-F., Chen, C.-W., Dong, C.-D. \& Kao, C.-M. 2013 Assessment of toxicity of polycyclic aromatic hydrocarbons in sediments of Kaohsiung Harbor, Taiwan. Science of the Total Environment 463, 1174-1181.

Chen, C.-W. \& Chen, C.-F. 20II Distribution, origin, and potential toxicological significance of polycyclic aromatic hydrocarbons (PAHs) in sediments of Kaohsiung Harbor, Taiwan. Marine Pollution Bulletin 63, 417-423.

Chen, C.-W., Kao, C.-M., Chen, C.-F. \& Dong, C.-D. 2007 Distribution and accumulation of heavy metals in the sediments of Kaohsiung Harbor, Taiwan. Chemosphere 66, 1431-1440.

Chiou, C. T. 2002 Partition and Adsorption of Organic Contaminants in Environmental Systems. Wiley Interscience, New Jersey.

Connor, T. P., Daskalakis, K. D., Hyland, J. L., Paul, J. F. \& Summers, J. K. 1998 Comparisons of sediment toxicity with predictions based on chemical guidelines. Environmental Toxicology and Chemistry 17, 468-471.
De Luca, G., Furesia, A., Micerab, G., Panzanellib, A., Piub, P. C., Pilob, M. I., Spanob, N. \& Gavino, S. 2005 Nature, distribution and origin of polycyclic aromatic hydrocarbons (PAHs) in the sediments of Olbia harbor (Northern Sardinia, Italy). Marine Pollution Bulletin 50, 1223-1232.

Dobaradaran, S., Mahvi, A. H., Nabizadeh, R., Mesdaghinia, A., Naddafi, K., Yunesian, M., Rastkari, N. \& Nazmara, S. 2010 Hazardous organic compounds in groundwater near Tehran automobile industry. Bulletin of Environmental Contamination \& Toxicology 85, 530-533.

European Commission 20II Polycyclic Aromatic Hydrocarbons (PAH) Factsheet. JRC Technical Notes. 4th edn. European Union Publications, Luxembourg.

Fang, M.-D., Lee, C.-L. \& Yu, C.-S. 2003 Distribution and source recognition of polycyclic aromatic hydrocarbons in the sediments of Hsin-ta Harbour and adjacent coastal areas, Taiwan. Marine Pollution Bulletin 46, 941-953.

Fang, M.-D., Hsieh, P.-C., Ko, F.-C., Baker, J. E. \& Lee, C.-L. 2007 Sources and distribution of polycyclic aromatic hydrocarbons in the sediments of Kaoping river and submarine canyon system, Taiwan. Marine Pollution Bulletin 54, 1179-1189.

Guinan, J., Charlesworth, M., Service, M. \& Oliver, T. 20or Sources and geochemical constraints of polycyclic aromatic hydrocarbons (PAHs) in sediments and mussels of two Northern Irish Sea-loughs. Marine Pollution Bulletin 42, 1073-1081.

Guitart, C., García-Flor, N., Miquel, J., Fowler, S. \& Albaigés, J. 20Io Effect of the accumulation of polycyclic aromatic hydrocarbons in the sea surface microlayer on their coastal air-sea exchanges. Journal of Marine Systems 79, 210-217.

Guo, W., He, M., Yang, Z., Lin, C., Quan, X. \& Wang, H. 2007 Distribution of polycyclic aromatic hydrocarbons in water, suspended particulate matter and sediment from Daliao River watershed, China. Chemosphere 68, 93-104.

Hong, H., Xu, L., Zhang, L., Chen, J., Wong, Y. \& Wan, T. 1995 Special guest paper: environmental fate and chemistry of organic pollutants in the sediment of Xiamen and Victoria Harbours. Marine Pollution Bulletin 31, 229-236.

Hung, J.-J. \& Hsu, C.-L. 2004 Present state and historical changes of trace metal pollution in Kaoping coastal sediments, southwestern Taiwan. Marine Pollution Bulletin 49, 986-998.

Jiang, J.-J., Lee, C.-L., Fang, M.-D. \& Liu, J. T. 2009 Polycyclic aromatic hydrocarbons in coastal sediments of southwest Taiwan: an appraisal of diagnostic ratios in source recognition. Marine Pollution Bulletin 58, 752-760.

Jones-Lee, A. \& Lee, G. F. 2005 Unreliability of co-occurrencebased sediment quality guidelines for contaminated sediment evaluations at Superfund/hazardous chemical sites. Remediation Journal 15, 19-33.

Karcher, W. 1988 Spectral Atlas of Polycyclic Aromatic Compounds. Vol. 2. Kluwer, Dordrecht, The Netherlands.

Katsoyiannis, A., Terzi, E. \& Cai, Q.-Y. 2007 On the use of PAH molecular diagnostic ratios in sewage sludge for the understanding of the PAH sources. Is this use appropriate? Chemosphere 69, 1337-1339.

Kilikidis, S., Kamarianos, A., Karamanlis, X. \& Gianakou, U. 1994 Determination of polycyclic aromatic hydrocarbons in the 
effluents of an urban waste treatment plant and the water, sediments and mussels of the receiver Thermaikos Gulf (N. Greece). Fresenius Environ Bull 3, 293-299.

Kim, G. B., Maruya, K. A., Lee, R. F., Lee, J.-H., Koh, C.-H. \& Tanabe, S. 1999 Distribution and sources of polycyclic aromatic hydrocarbons in sediments from Kyeonggi Bay, Korea. Marine Pollution Bulletin 38, 7-15.

Li, G., Xia, X., Yang, Z., Wang, R. \& Voulvoulis, N. 2006 Distribution and sources of polycyclic aromatic hydrocarbons in the middle and lower reaches of the Yellow River, China. Environmental Pollution 144, 985-993.

Liu, L.-b., Yan, L., Lin, J.-m., Ning, T., Hayakawa, K. \& Maeda, T. 2007 Development of analytical methods for polycyclic aromatic hydrocarbons (PAHs) in airborne particulates: a review. Journal of Environmental Sciences 19, 1-11.

Liu, Y., Chen, L., Jianfu, Z., Qinghui, H., Zhiliang, Z. \& Hongwen, G. 2008 Distribution and sources of polycyclic aromatic hydrocarbons in surface sediments of rivers and an estuary in Shanghai, China. Environmental Pollution 154, 298-305.

Long, E. R., MacDonald, D. D., Smith, S. L. \& Calder, F. D. 1995 Incidence of adverse biological effects within ranges of chemical concentrations in marine and estuarine sediments. Environmental Management 19, 81-97.

Long, E. R., Field, L. J. \& MacDonald, D. D. 1998 Predicting toxicity in marine sediments with numerical sediment quality guidelines. Environmental Toxicology and Chemistry 17, 714-727.

Long, E. R., MacDonald, D. D., Severn, C. G. \& Hong, C. B. 2000 Classifying probabilities of acute toxicity in marine sediments with empirically derived sediment quality guidelines. Environmental Toxicology and Chemistry 19, 2598-2601.

Macrae, J. D. \& Hall, K. J. 1998 Biodegradation of polycyclic aromatic hydrocarbons (PAH) in marine sediment under denitrifying conditions. Water Science and Technology 38, 177-185.

Magi, E., Bianco, R., Ianni, C. \& Di Carro, M. 2002 Distribution of polycyclic aromatic hydrocarbons in the sediments of the Adriatic Sea. Environmental Pollution 119, 91-98.

Man, Y. B., Kang, Y., Wang, H. S., Lau, W., Li, H., Sun, X. L., Giesy, J. P., Chow, K. L. \& Wong, M. H. 2013 Cancer risk assessments of Hong Kong soils contaminated by polycyclic aromatic hydrocarbons. Journal of Hazardous Materials 261, 770-776.

Marin, V., Moreno, M., Vassallo, P., Vezzulli, L. \& Fabiano, M. 2008 Development of a multistep indicator-based approach (MIBA) for the assessment of environmental quality of harbours. ICES Journal of Marine Science: Journal du Conseil 65, 1436-1441.

Menzie, C. A., Potocki, B. B. \& Santodonato, J. 1992 Exposure to carcinogenic PAHs in the environment. Environmental Science \& Technology 26, 1278-1284.

MOOPAM 1999 Manual of Oceanographic Observations and Pollutant Analyses Methods, 3rd edn. Section 6. Regional Organization for the Protection of the Marine Environment (ROPME), Kuwait.

Nadal, M., Schuhmacher, M. \& Domingo, J. 2004 Levels of PAHs in soil and vegetation samples from Tarragona County, Spain. Environmental Pollution 132, 1-11.
Notar, M., Leskovšek, H. \& Faganeli, J. 200I Composition, distribution and sources of polycyclic aromatic hydrocarbons in sediments of the Gulf of Trieste, Northern Adriatic Sea. Marine Pollution Bulletin 42, 36-44.

Oen, A. M., Cornelissen, G. \& Breedveld, G. D. 2006 Relation between PAH and black carbon contents in size fractions of Norwegian harbor sediments. Environmental Pollution 141, 370-380.

Pereira, W. E., Hostettler, F. D., Luoma, S. N., van Geen, A., Fuller, C. C. \& Anima, R. J. 1999 Sedimentary record of anthropogenic and biogenic polycyclic aromatic hydrocarbons in San Francisco Bay, California. Marine Chemistry 64, 99-113.

Qiao, M., Wang, C., Huang, S., Wang, D. \& Wang, Z. 2006 Composition, sources, and potential toxicological significance of PAHs in the surface sediments of the Meiliang Bay, Taihu Lake, China. Environment International 32, 28-33.

Roach, A. 2005 Assessment of metals in sediments from Lake Macquarie, New South Wales, Australia, using normalisation models and sediment quality guidelines. Marine Environmental Research 59, 453-472.

Salvo, V., Gallizia, I., Moreno, M. \& Fabiano, M. 2005 Fungal communities in PAH-impacted sediments of Genoa-Voltri harbour (NW Mediterranean, Italy). Marine Pollution Bulletin 50, 553-559.

Savinov, V. M., Savinova, T. N., Matishov, G. G., Dahle, S. \& Næs, K. 2003 Polycyclic aromatic hydrocarbons (PAHs) and organochlorines (OCs) in bottom sediments of the Guba Pechenga, Barents Sea, Russia. Science of the Total Environment 306, 39-56.

Soclo, H., Garrigues, P. \& Ewald, M. 2000 Origin of polycyclic aromatic hydrocarbons (PAHs) in coastal marine sediments: case studies in Cotonou (Benin) and Aquitaine (France) areas. Marine Pollution Bulletin 40, 387-396.

Sprovieri, M., Feo, M. L., Prevedello, L., Manta, D. S., Sammartino, S., Tamburrino, S. \& Marsella, E. 2007 Heavy metals, polycyclic aromatic hydrocarbons and polychlorinated biphenyls in surface sediments of the Naples harbour (southern Italy). Chemosphere 67, 998-1009.

Storelli, M. \& Marcotrigiano, G. 2000 Polycyclic aromatic hydrocarbon distributions in sediments from the Mar Piccolo, Ionian Sea, Italy. Bulletin of Environmental Contamination and Toxicology 65, 537-544.

Tolun, L., Okay, O., Gaines, A., Tolay, M., Tüfekçi, H. \& Kıratlı, N. 200I The pollution status and the toxicity of surface sediments in Izmit Bay (Marmara Sea), Turkey. Environment International 26, 163-168.

Ünlü, S. \& Alpar, B. 2006 Distribution and sources of hydrocarbons in surface sediments of Gemlik Bay (Marmara Sea, Turkey). Chemosphere 64, 764-777.

US EPA 1993 Provisional Guidance for Quantitative Risk Assessment of Polycyclic Aromatic Hydrocarbons. EPA/600/ R/089, Office of Research and Development, US Environmental Protection Agency, Washington, DC, USA.

Viguri, J., Verde, J. \& Irabien, A. 2002 Environmental assessment of polycyclic aromatic hydrocarbons (PAHs) in surface 
sediments of the Santander Bay, Northern Spain. Chemosphere 48, 157-165.

Wakeman, T. H. \& Themelis, N. J. 20oI A basin-wide approach to dredged material management in New York/New Jersey Harbor. Journal of Hazardous Materials 85, 1-13.

Wang, H. S., Cheng, Z., Liang, P., Shao, D. D., Kang, Y., Wu, S. C., Wong, C. K. C. \& Wong, M. H. 20I0 Characterization of PAHs in surface sediments of aquaculture farms around the Pearl River Delta. Ecotoxicology and Environmental Safety 73, 900-906.

Wang, X.-C., Zhang, Y.-X. \& Chen, R. F. 20oI Distribution and partitioning of polycyclic aromatic hydrocarbons (PAHs) in different size fractions in sediments from Boston Harbor, United States. Marine Pollution Bulletin 42, 1139-1149.

Wenzl, T., Simon, R., Anklam, E. \& Kleiner, J. 2006 Analytical methods for polycyclic aromatic hydrocarbons (PAHs) in food and the environment needed for new food legislation in the European Union. TrAC Trends in Analytical Chemistry 25, 716-725.

Xia, X. \& Wang, R. 2008 Effect of sediment particle size on polycyclic aromatic hydrocarbon biodegradation: importance of the sediment-water interface. Environmental Toxicology and Chemistry 27, 119-125.

Yan, W., Chi, J., Wang, Z., Huang, W. \& Zhang, G. 2009 Spatial and temporal distribution of polycyclic aromatic hydrocarbons (PAHs) in sediments from Daya Bay, South China. Environmental Pollution 157, 1823-1830.

Yang, G.-P. 2000 Polycyclic aromatic hydrocarbons in the sediments of the South China Sea. Environmental Pollution 108, 163-171.

Yunker, M. B., Macdonald, R. W., Vingarzan, R., Mitchell, R. H., Goyette, D. \& Sylvestre, S. 2002 PAHs in the Fraser River basin: a critical appraisal of PAH ratios as indicators of $\mathrm{PAH}$ source and composition. Organic Geochemistry 33, 489-515.

Zakaria, M. P., Takada, H., Tsutsumi, S., Ohno, K., Yamada, J., Kouno, E. \& Kumata, H. 2002 Distribution of polycyclic aromatic hydrocarbons (PAHs) in rivers and estuaries in Malaysia: a widespread input of petrogenic PAHs. Environmental Science \& Technology 36, 1907-1918.

Zeng, F., Cui, K., Xie, Z., Liu, M., Li, Y., Lin, Y., Zeng, Z. \& Li, F. 2008 Occurrence of phthalate esters in water and sediment of urban lakes in a subtropical city, Guangzhou, South China. Environment International 34, 372-380.

Zhou, J. L., Fileman, T. W., Evans, S., Donkin, P., Llewellyn, C., Readman, J. W., Mantoura, R. F. C. \& Rowland, S. J. 1998 Fluoranthene and pyrene in the suspended particulate matter and surface sediments of the Humber Estuary, UK. Marine Pollution Bulletin 36, 587-597.

First received 5 February 2016; accepted in revised form 20 May 2016. Available online 10 June 2016 